\title{
PENGARUH KONFLIK KERJA, BEBAN KERJA SERTA LINGKUNGAN KERJA TERHADAP STRES PEGAWAI PT. PLN (Persero) AREA MADIUN RAYON MAGETAN
}

\author{
Aglis Andhita Hatmawan \\ STIE Dharma Iswara Madiun
}

\begin{abstract}
ABSTRAK
Kajian ini bertujuan untuk menganalisis pengaruh konflik kerja, beban kerja dan lingkungan kerja stres bagi karyawan. Dalam populasi penelitian ini digunakan adalah seluruh karyawan PT PLN (Persero) di Area Madiun Rayon Magetan. Teknik sampling yang digunakan adalah total sampling dengan jumlah sampel 80 orang. Pengumpulan data dilakukan dengan kuesioner dan hasilnya dianalisis dengan menggunakan analisis deskriptif kuantitatif. Hasil Regresi analisis menunjukkan bahwa konflik kerja dan beban kerja berpengaruh pada stres kerja karyawan PT PLN (Persero) di Area Madiun Rayon Magetan.
\end{abstract}

Kata kunci: Konflik Kerja, Beban Kerja, Lingkungan, Stress

\section{PENDAHULUAN}

Perubahan lingkungan yang cepat, yang ditandai dengan kemajuan informasi, perubahan selera pasar, perubahan demografi, fluktuasi ekonomi, dan kondisi dinamis lain menuntut organisasi untuk merespon perubahan yang terjadi agar tetap eksis dalam persaingan global. Organisasi seringkali harus merubah struktur dan bentuk organisasinya agar organisasi dapat merespon perubahan yang terjadi. Perubahan organisasi tersebut akan membawa dampak terhadap setiap individu yang berada dalam organisasi. Setiap individu yang menjadi bagian dari suatu organisasi dituntut untuk mengembangkan dan merealisasikan kompetensinya secara penuh.

Perubahan kondisi lingkungan organisasi baik internal maupun eksternal mendorong organisasi untuk merespon dengan cepat (responsive) dan beradaptasi (adaptive) dengan lingkungan pasar yang penuh dengan persaingan. Organisasi harus semakin fleksibel untuk menyesuaikan diri dalam lingkungan persaingan yang semakin kompetitif. Fleksibilitas organisasi ditentukan oleh sumberdaya yang memiliki kemampuan dan keterampilan yang tinggi (knowledge asset) yang menjadikan organisasi memiliki keunggulan kompetitif (competitive advantage) sehingga dapat memenangkan persaingan. Dalam era globalisasi seperti sekarang ini, persaingan dalam pasar akan semakin ketat. Agar dapat lebih unggul dalam persaingan perusahaan harus memiliki kinerja yang lebih baik, yang tergantung sampai seberapa keunggulan perusahaan tersebut dikelola oleh para manajer dan para pengambil keputusan puncak.

Berkaitan dengan dunia kerja, segala bentuk kegiatan menuntut adanya interaksi antara individu dengan lingkungan kerja itu sendiri. Interaksi ini dibutuhkan agar terbentuk suatu koordinasi, kerjasama dan sinergi yang baik dalam lingkungan kerja tersebut. Apabila interaksi individu dengan rekan sekerjanya maupun dengan lingkungan kerjanya tidak berjalan baik maka situasi ini akan menjadi situasi yang dapat menimbulkan stress.

Stres merupakan suatu kondisi ketegangan yang mempengaruhi emosi, proses berpikir dan kondisi seseorang.hasilnya stress yang terlalu besar dapat mengancam kemampuan seseorang untuk menghadapi lingkungan, yang akhirnya mengganggu pelaksanaan tugas tugasnya (Handoko, 2012:200). Jika seseorang/karyawan mengalami 
stres yang terlalu besar maka akan dapat menganggu kemampuan seseorang/karyawan tersebut untuk menghadapi lingkungannya dan pekerjaan yang akan dilakukannya.

Konflik di tempat kerja,pemberian kerja yang terlalu berlebihan terhadap karyawan dapat menimbulkan stress yang berkepanjangan, yaitu kondisi atau keadaan yang tidak menyenangkan yang dihadapi oleh setiap orang baik secara fisik maupun mental.Stres di lingkungan kerja dapat terjadi pada setiap level menejemen mulai dari top manajemen sampai pada karyawan biasa dan memberikan pengaruh buruk terhadap kinerja individu yag berdampak negatif terhadap kinerja perusahaan selain itu Lingkungan kerja juga sangat berpengaruh besar dalam sebuah tujuan organisasi (Anantan, Ellitan,2007:69).

Menurut Malayu Hasibuan (2013:199), konflik adalah suatu persaingan kurang sehat berdasarkan ambisi dalam hal - hal seperti ketidakcocokan, ketidaksetujuan atau ketegangan baik intra individu maupun interentitas social seperti individu, kelompok ataupun organisasi.

Anantan (2007:60), konflik adalah suatu kompetisi yang terjadi dalam suatu organisasi dapat terjadi karena adanya perbedaan pendapat mengenai tujuan perusahaan, antar bagian, antar unit kerja, para manajer yang bersaing dan berkonflik untuk memperebutkan posisi dan kekuasaan.

Selain itu Anantan (2007:61) mengutarakan bahwa konflik merupakan suasana batin yang berisi kegelisahan dan pertentangan antara dua motif atau lebih mendorong seseorang untuk melakukan dua tau lebih kegiatan yang saling bertentangan. Bila tidak dikendalikan secara baik akan menimbulkan perpecahan di antara individu yang ada dalam perusahaan.

Moorhead, Griffin, (2010:182), menyatakan bahwa konsekuensi final dari struktur peran yang lemah adalah kelebihan beban kerja (peran) yang terjadi ketika ekspektasi untuk peran tersebut melampaui kemampuan individual.Ketika seorang manajer memberikan beberapa tugas besar kepada seorang karyawan sekaligus sambil meningkatkan beban kerja regular orang tersebut, karywan tersebut mungkin akan mengalami beberapa kelebihan beban kerja.

Beban kerja yang bisa menyebabkan terjadinya stres kerja diantaranya adalah sistem pemberian tugas yang berlebihan, dan tekanan dan sikap pimpinan terhadap target kerja yang kurang adil dan tidak wajar. Hal-hal tersebut bisa menyebabkan terjadinya stres kerja karyawan (Abdurrahmat Fathoni, 2009:176).

Menurut Marwansyah (2012:11-13) Lingkungan kerja dikelompokan menjadi 2 kelompok yakni lingkungan eksternal dan lingkungan eksternal.Lingkungan eksternal adalah kekuatan utama di luar organisasi yang memiliki potensi untuk mempengaruhikeberhasilan suatu organisasi dalam mencapai tujuanya. Sedangkan lingkungan internal adalah faktoratau kondisi umum yang berada di dalam sebuah organisasi, yang mempengaruhi menejemen organisasi.

Lingkungan kerja yang baik akan mendorong seseorang ataupun kelompok untuk bekerja lebih baik dan bersikap positif seperti mempunyai kesetiaan yang tinggi, kegembiraan, kebanggaan dalam dinas, kerjasama dan kedisplinan dalam kewajiban dengan integritas dan kepercayaan penuh.

\section{HIPOTESIS}

Berdasar pembahasan di atas, maka hipotesis yang diajukan dalam penelitian ini adalah :

H1 : Terdapat pengaruh yang signifikan antara konflik kerja terhadap stres kerja pada karyawan baik secara parsial maupun simultan

$\mathrm{H} 2$ : Terdapat pengaruh yang signifikan antara beban kerja terhadap stres kerja pada karyawan baik secara parsial maupun simultan 
H3 : Terdapat pengaruh yang signifikan antara lingkungan kerja terhadap stres kerja pada karyawan baik secara parsial maupun simultan

\section{METODE PENELITIAN}

Penelitian ini dilakukan di kantor PT. PLN (Persero) Area Madiun Rayon Magetan, Jenis penelitian yang dilakukan adalah penelitian kuantitatif eksperimen berdasarkan survei, yaitu merupakan penelitian yang bertujuan untuk menguji atau mencari pengaruh tertentu untuk membantu si peneliti dalam memilih tindakan khusus selanjutnya (Sugiyono, 2014:6-7). Populasi dalam penelitian ini adalah seluruh karyawan PT. PLN (Persero) Area Madiun Rayon Magetan sejumlah 80 orang karyawan . Untuk itu jumlah sampel dalam penelitian ini adalah sebanyak 80 sampel. Pengambilan sampel dalam penelitian ini menggunakan tehnik total sampling, yaitu tehnik penetapan jumlah sampel dengan mengikutsertakan seluruh populasi.

\section{HASIL ANALISIS}

\section{a. Uji Validitas dan Reliabilitas Data}

Data yang digunakan dalam penelitian ini telah lolos uji validitas dan reliabilitas data.

\section{b. Analisis Regresi Linier Berganda}

Hasil perhitungan regresi antara variabel konflik kerja $\left(\mathrm{X}_{1}\right)$, beban kerja $\left(\mathrm{X}_{2}\right)$, dan lingkungan kerja $\left(\mathrm{X}_{3}\right)$ sebagai variabel independent terhadap stres kerja pada karyawan PT. PLN (Persero) Area Madiun Rayon Magetan sebagai variabel dependent (Y) dapat dilihat pada tabel berikut:

Tabel 1

\section{Hasil Analisis Regresi}

Coefficients

\begin{tabular}{|c|c|c|c|c|c|c|c|}
\hline \multirow[t]{2}{*}{ Model } & \multicolumn{2}{|c|}{$\begin{array}{l}\text { Unstandardized } \\
\text { Coefficients }\end{array}$} & \multirow{2}{*}{$\begin{array}{c}\text { Standardized } \\
\text { Coefficients } \\
\text { Beta }\end{array}$} & \multirow[t]{2}{*}{$\mathrm{t}$} & \multirow[t]{2}{*}{ Sig. } & \multicolumn{2}{|c|}{ Collinearity Statistics } \\
\hline & B & Std. Error & & & & Tolerance & VIF \\
\hline 1. (Constant) & 896 & ,360 & & 2,486 & ,015 & & \\
\hline Konflik Kerja & ,418 & ,049 & ,558 & 8,495 & ,000 & ,817 & 1,224 \\
\hline Beban Kerja & ,362 & ,053 &, 452 & 6,854 & ,000 & 812 & 1,232 \\
\hline Lingkungan Kerja &,- 008 & ,063 &,- 008 &,- 132 & ,895 & 992 & 1,008 \\
\hline
\end{tabular}

Dari hasil uji regresi pada Tabel 4.11 dapat diformulasikan persamaan regresi sebagai berikut:

$$
\begin{aligned}
Y & =a+b_{1} X_{1}+b_{2} X_{2}-b_{3} X_{3}+e \\
& =0,896+0,418 X_{1}+0,362 X_{2}-0,008 X_{3}
\end{aligned}
$$

Keterangan:

$\mathrm{Y}=$ stres kerja pada Karyawan PT. PLN (Persero) ArSea Madiun Rayon Magetan

$\mathrm{a}=$ konstanta

$\mathrm{X}_{1}=$ konflik kerja

$\mathrm{X}_{2}=$ beban kerja

$\mathrm{X}_{3}=$ lingkungan kerja 
Dari persamaan tersebut, dapat diidentifikasikan beberapa hal sebagai berikut:

a. Nilai konstanta sebesar 0,896; menunjukkan bahwa stres kerja pada karyawan PT. PLN (Persero) Area Madiun Rayon Magetan akan bernilai konstan sebesar 0,896, apabila variabel konflik kerja $\left(\mathrm{X}_{1}\right)$, beban kerja $\left(\mathrm{X}_{2}\right)$, dan lingkungan kerja $\left(\mathrm{X}_{3}\right)$ sama dengan nol (tidak ada), dengan asumsi faktor-faktor lain tetap atau tidak berubah nilainya.

b. Variabel konflik kerja $\left(\mathrm{X}_{1}\right)$ yang bernilai sebesar 0,418 (positif) menunjukkan besarnya pengaruh konflik kerja terhadap stres kerja pada Karyawan PT. PLN (Persero) Area Madiun Rayon Magetan berkorelasi positif sehingga setiap kenaikan pada konflik kerja menyebabkan naiknya stres kerja pada karyawan PT. PLN (Persero) Area Madiun Rayon Magetan sebesar 0,418.

c. Variabel beban kerja $\left(\mathrm{X}_{2}\right)$ yang bernilai sebesar 0,362 (positif) menunjukkan besarnya pengaruh beban kerja terhadap stres kerja pada karyawan PT. PLN (Persero) Area Madiun Rayon Magetan berkorelasi positif sehingga setiap kenaikan pada beban kerja menyebabkan naiknya stres kerja pada Karyawan PT. PLN (Persero) Area Madiun Rayon Magetan sebesar 0,362.

d. Variabel lingkungan kerja $\left(\mathrm{X}_{3}\right)$ yang bernilai sebesar 0,008 (negatif) menunjukkan besarnya pengaruh lingkungan kerja terhadap stres kerja pada karyawan PT. PLN (Persero) Area Madiun Rayon Magetan berkorelasi negatif sehingga setiap kenaikan pada lingkungan kerja menyebabkan turunnya stres kerja pada karyawan PT. PLN (Persero) Area Madiun Rayon Magetan sebesar 0,008 satuan.

e. Dilihat dari nilai pada koefisien regresi, maka dapat diketahui bahwa konflik kerja, beban kerja, dan lingkungan kerja berpengaruh positif terhadap stres kerja pada karyawan PT. PLN (Persero) Area Madiun Rayon Magetan.

\section{Analisis Koefisien Determinasi (Uji $\mathbf{R}^{\mathbf{2}}$ )}

Koefisien determinasi $\left(\mathrm{R}^{2}\right)$ digunakan untuk mengetahui seberapa besar pengaruh variabel independen secara serentak terhadap variabel dependen (Duwi Priyatno, 2013:56).

a. Multiple Coeficient of Determination ( $R$ Square)

Dari hasil penelitian pada Tabel 3 dapat diketahui bahwa besarnya Multiple Coeficient of Determination ( $R$ Square) adalah 0,732 atau 73,2\% yang berarti 73,2\% stres kerja pada karyawan PT. PLN (Persero) Area Madiun Rayon Magetan dapat dijelaskan oleh variabel konflik kerja, beban kerja, dan lingkungan kerja, sedangkan sisanya, yaitu sebesar 26,8\% dijelaskan oleh sebab-sebab lain yang tidak diteliti dalam penelitian ini, misalnya kepemimpinan dan kompensasi.

b. Uji t

Dari hasil perhitungan dalam Tabel 3, pada variabel konflik kerja diperoleh nilai $t_{\text {hitung }}$ sebesar 8,495 lebih besar dari $t_{\text {tabel }}(1,671)$, sedangkan variabel beban kerja diperoleh nilai thitung sebesar 6,854, maka dapat disimpulkan bahwa ada pengaruh yang signifikan antara konflik kerja dan beban kerja terhadap stres kerja pada karyawan PT. PLN (Persero) Area Madiun Rayon Magetan. Sedangkan untuk variabel lingkungan kerja diperoleh nilai $t_{\text {hitung }}$ sebesar $-0,132$ lebih kecil dari $t_{\text {tabel }}(1,671)$, Hal ini berarti tidak ada pengaruh yang signifikan antara lingkungan kerja dengan stres kerja pada Karyawan PT. PLN (Persero) Area Madiun Rayon Magetan. 
c. Uji Secara Serentak (Uji F)

Melalui penghitungan data dengan menggunakan program SPSS Release 20,

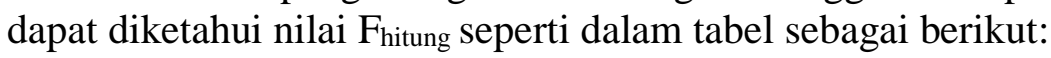

Tabel 2

ANOVA

ANOVA $^{\mathrm{B}}$

\begin{tabular}{llrrrrr}
\hline & Model & $\begin{array}{c}\text { Sum of } \\
\text { Squares }\end{array}$ & df & $\begin{array}{c}\text { Mean } \\
\text { Square }\end{array}$ & F & Sig. \\
\hline 1 & Regression & 10,791 & 3 & 3,597 & 69,156 &, $000^{\alpha}$ \\
& Residual & 3,953 & 76 &, 052 & & \\
& Total & 14,744 & 79 & & & \\
\hline a. & Predictors : (Constant), Lingkungan Kerja, Konflik Kerja, Beban Kerja & & \\
b. & Dependent Variable : Stres Kerja
\end{tabular}

Sumber: Hasil Olah Data SPSS, Regression,

Kriteria pengujian yang digunakan adalah dengan menentukan nilai $F_{\text {tabel }}$ terlebih dahulu. Nilai $F_{\text {tabel }}$ diperoleh melalui penentuan nilai level of significant $(\alpha)$ serta $\mathrm{df}$. pembilang (df1) dan df. penyebut (df2). Dalam penelitian ini, dipilih level of significant $(\alpha)=0,05(5 \%)$. Jumlah sampel yang digunakan dalam penelitian adalah 80 orang responden dengan jumlah variabel bebas sebanyak 3 (tiga) buah, yaitu konflik kerja $\left(\mathrm{X}_{1}\right)$, beban kerja $\left(\mathrm{X}_{2}\right)$, dan lingkungan kerja $\left(\mathrm{X}_{3}\right)$. Dengan demikian diperoleh nilai df. pembilang $(\mathrm{df} 1)=\mathrm{k}=3$ dan df. penyebut $(\mathrm{df} 2)=\mathrm{n}-\mathrm{k}-1=80-3-1=76$. Pada tabel $\mathrm{F}$, dengan level of significant $(\alpha)=0,05(5 \%)$ diperoleh nilai $\mathrm{F}_{\text {tabel }}=2,60$.

Dari hasil perhitungan yang ditunjukkan oleh Tabel 4.12. tersebut di atas, diperoleh nilai $F_{\text {hitung }}$ sebesar 69,156 . Dari angka tersebut berarti $F_{\text {hitung }}(69,156)$ lebih besar daripada $F_{\text {tabel }}(2,60)$, maka Ho ditolak. Hal ini berarti terdapat pengaruh yang signifikan antara konflik kerja, beban kerja, dan lingkungan kerja dengan stres kerja pada Karyawan PT. PLN (Persero) Area Madiun Rayon Magetan. Dengan demikian hipotesis penelitian yang menyatakan "Konflik kerja, beban kerja, dan lingkungan kerja secara simultan berpengaruh terhadap stres kerja pada kayawan PT. PLN (Persero) Area Madiun Rayon Magetan" terbukti kebenarannya.

\section{PEMBAHASAN}

a. Pengaruh Konflik Kerja terhadap Stres Kerja pada Karyawan PT. PLN (Persero) Area Madiun Rayon Magetan

Hasil penelitian menunjukkan adanya pengaruh yang signifikan antara konflik kerja terhadap stres kerja pada karyawan PT. PLN (Persero) Area Madiun Rayon Magetan. Dari uji t diperoleh besarnya nilai $t_{\text {hitung }}$ sebesar 8,495 lebih besar dari $t_{\text {tabel }}$ $(1,671)$ dan nilai $p$ value sebesar 0,000 lebih kecil dari $\alpha(0,05)$. Sesuai dengan pendapat dari Lina anantan dan Lena Ellitan (2007: 67), diketahui bahwa konflik mempunyai hubungan dengan stress kerja. Konflik peran muncul manakala karyawan tidak mengetahui apa yang diharapkan oleh pihak manajemen dari dirinya. Sebagian besar karyawan yang bekerja di suatu perusahaan yang tidak memiliki struktur secara jelas, mengalami stres karena konflik peran. Mereka stres karena ketidakjelasan peran dalam bekerja dan tidak tahu apa yang diharapkan oleh manajemen. Kenyataan seperti ini mungkin banyak dialami pekerja di Indonesia, dimana perusahaan atau organisasi tidak punya garis-garis haluan yang jelas, aturan main, visi dan misi yang seringkali tidak dikomunikasikan pada seluruh karyawan. Akibatnya, sering muncul rasa 
ketidakpuasan kerja, ketegangan, menurunnya prestasi hingga akhirnya timbul keinginan untuk meninggalkan pekerjaan.

\section{b. Pengaruh Beban Kerja terhadap Stres Kerja pada Karyawan PT. PLN (Persero) Area Madiun Rayon Magetan}

Hasil penelitian juga menunjukkan bahwa beban kerja berpengaruh terhadap stres kerja pada karyawan PT. PLN (Persero) Area Madiun Rayon Magetan. Berdasarkan uji $\mathrm{t}$ diketahui bahwa nilai thitung sebesar 6,854 lebih besar dari tabel $(1,671)$, maka Ho ditolak dan Ha diterima. Hal ini berarti ada pengaruh yang signifikan antara beban kerja dengan stres kerja pada karyawan PT. PLN (Persero) Area Madiun Rayon Magetan. Menurut dari Lina anantan dan Lena Ellitan (2007: 67), beban kerja yang bisa menyebabkan terjadinya stres kerja di antaranya adalah sistem pemberian tugas, kesulitan dari tugas, ketercukupan waktu untuk penyelesaian, ada tidaknya instruktur kerja, maupun tingkat kelelahan karyawan dalam menyelesaikan pekerjaan. Hal-hal tersebut bisa menyebabkan terjadinya stres kerja karyawan. Pada PT. PLN (Persero) Area Madiun Rayon Magetan, adanya beban kerja yang berlebihan, seperti karena adanya gangguan jaringan yang sewaktu-waktu terjadi, membuat karyawan bagian lapangan harus bersedia ditugaskan setiap saat. Hal ini mungkin akan dianggap suatu beban oleh karyawan, sehingga menyebabkan karyawan merasa tertekan dan stres dalam menghadapi tugas dan pekerjaan.

\section{c. Pengaruh Lingkungan Kerja terhadap Stres Kerja pada Karyawan PT. PLN (Persero) Area Madiun Rayon Magetan}

Hasil penelitian juga menunjukkan bahwa lingkungan kerja tidak berpengaruh terhadap stres kerja pada karyawan PT. PLN (Persero) Area Madiun Rayon Magetan.

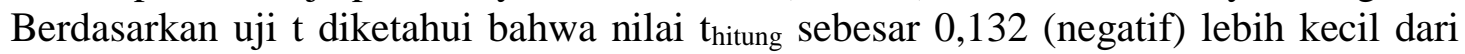
$\mathrm{t}_{\text {tabel }}(1,671)$, maka Ho diterima dan Ha ditolak. Hal ini berarti tidak ada pengaruh yang signifikan antara lingkungan kerja dengan stres kerja pada karyawan PT. PLN (Persero) Area Madiun Rayon Magetan. Menurut Marwansyah (2012:12-13) lingkungan kerja adalah sesuatu kekuatan tau faktor di luar ataupun di dalam organisai yang dapat mempengaruhi keberhasilan organisasi, dan mempengaruhi baik secara langsung maupun tidak langsung seseorang atau sekelompok orang di dalam melaksanakan aktivitasnya.

Berdasarkan hasil analisis data diketahui bahwa lingkungan kerja tidak berpengaruh terhadap stres kerja pada karyawan PT. PLN (Persero) Area Madiun Rayon Magetan. Hal ini mungkin bertentangan dengan pendapat yang menyatakan bahwa lingkungan kerja yang baik akan mendorong seseorang untuk bekerja lebih baik dan bersikap positif seperti mempunyai kesetiaan yang tinggi, kegembiraan, kebanggaan dalam dinas, kerjasama dan kedisplinan dalam kewajiban. Tidak berpengaruhnya lingkungan kerja terhadap stres kerja pada karyawan PT. PLN (Persero) Area Madiun Rayon Magetan dimungkinkan karena lingkungan kerja pada PT. PLN (Persero) Area Madiun Rayon Magetan bukanlah dasar pertimbangan bagi karyawan dalam melaksanakan tugas dan pekerjaan. Karyawan lebih mempertimbangkan konflik yang ada dalam pekerjaan dan beban kerja yang berlebih dibandingkan lingkungan kerja dalam menjalankan tugas. 
d. Pengaruh Konflik Kerja, Beban Kerja, dan Lingkungan Kerja terhadap Stres Kerja pada Karyawan PT. PLN (Persero) Area Madiun Rayon Magetan

Berdasarkan hasil penelitian diketahui bahwa konflik kerja, beban kerja, dan lingkungan kerja secara bersama-sama berpengaruh terhadap stres kerja pada karyawan PT. PLN (Persero) Area Madiun Rayon Magetan. Hal ini dibuktikan dengan

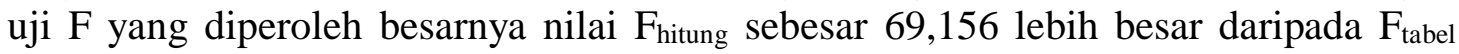
$(2,60)$.

Konflik kerja, beban kerja, dan lingkungan kerja secara simultan berpengaruh terhadap stres kerja pada karyawan PT. PLN (Persero) Area Madiun Rayon Magetan. Jika seorang karyawan mengalami konflik dan pekerjaan, merasa mendapat beban kerja yang tidak sesuai dengan tigas dan kemampuannya,serta adanya lingkungan kerja yang tidak nyaman dan tidak mendukung karyawan untuk dapat menjalankan aktivitasnya dengan baik, maka karyawan tersebut akan merasa stres dan tertekan.

Konflik antar karyawan, beban kerja yang menumpuk, serta lingkungan kerja yang buruk dapat menyebabkan stres kerja pada karyawan. Sebaliknya, hubungan yang harmonis dan dinamis di antara karyawan maupun pimpinan, pembagian tugas yang sesuai dengan jenjang jabatan serta kemampuan karyawan, serta lingkungan kerja yang kondusif akan membuat karyawan merasa nyaman dan dapat bekerja dengan tenang.

\section{KESIMPULAN}

Penelitian ini bertujuan untuk mengetahui pengaruh dari konflik kerja, beban kerja, dan lingkungan kerja terhadap stres kerja pada karyawan PT. PLN (Persero) Area Madiun Rayon Magetan. Berdasarkan hasil analisis data dapat ditarik beberapa kesimpulan bahwa konflik kerja, beban kerja, dan lingkungan kerja secara simultan (bersama sama) berpengaruh terhadap stres kerja pada kayawan PT. PLN. Dari hasil penelitian ini juga menunjukkan bahwa Konflik kerja dan beban kerja merupakan faktor yang paling berpengaruh terhadap stres kerja pada kayawan PT. PLN (Persero) Area Madiun Rayon Magetan.

\section{SARAN}

Berdasarkan hasil penelitian tersebut di atas, dalam penelitian ini dapat disampaikan saran-saran sebagai berikut:

1. Bagi PT. PLN (Persero) Area Madiun Rayon Magetan

a. Perlunya dibuat suatu kebijakan terkait dengan pembagian kerja yang sesuai dengan kompetensi dan kinerja karyawan agar mereka tetap memiliki motivasi dalam bekerja walaupun dengan beban kerja yang tinggi.

b. Perlu strategi pengelolaan stres pada karyawan untuk meminimalisir stres kerja akibat adanya konflik kerja dan beban kerja yang berlebih. Misalnya, dengan melakukan pertukaran shift kerja yang optimal, kegiatan di luar kerja, dan outbond.

c. Perlu mengoptimalkan konflik dengan mendinamiskan iklim kerja yang sehat.

2. Bagi peneliti sejenis

Perlu dilakukan penelitian lebih lanjut mengenai rasio beban kerja karyawan dan juga penghitungan tenaga kerja karyawan dikaitkan dengan kelelahan kerja karyawan.

\section{DAFTAR PUSTAKA}

Anantan,L.,dan Ellitan,L., 2007. Manajemen Sumber Daya Manusia dalam Bisnis Modern. Bandung: Alfabeta. 
Arikunto, Suharsimi. 2013. Prosedur Penelitian Suatu Pendekatan Praktik. Jakarta: Rineka Cipta.

Beehr, T and Newman, J. 2008. Gejala-Gejala Stress Kerja. http://www.epsikologi.com/masalah/stress.htm. Diakses Juni 2014.

Fathoni, Abdurrahmat. 2009. Organisasi dan Manejemen Sumber Daya Manusia. Jakarta: Rineka Cipta

Handoko, T. Hani. 2012. Manajemen Personalia dan Sumberdaya Manusia. Edisi Kedua. Yogyakarta: BPFE UGM.

Handoko, T. Hani. 2013. Manajemen Personalia dan Sumberdaya Manusia. Edisi Kedua. Yogyakarta: BPFE UGM.

Hasibuan,Malayu S.P.2013.Manajemen Sumber Daya Manusia.Jakarta: Bumi Aksara.

Marwansyah. 2012. Manajemen Sumber Daya Manusia. Bandung: Alfabeta

Moorhead, G and Griffin, R. 2013. Perilaku Organisasi Manajemen Sumber Daya Manusia dan Organisasi. Jakarta : Salemba Empat.

Priyatno, Duwi.2013. Analisis Korelasi, Regresi dan Multivariate dengan SPSS. Yogyakarta : Gava Media

Robbins, Stephens P., 2010. Manajemen. Edisi Kesepuluh. Jakarta : Erlangga.

Siagian, Sondang P., 2014. Manajemen Sumber Daya Manusia. Jakarta: Bumi Aksara.

Sugiyono. 2014. Metode Penelitian Kuantitatif Kualitatif dan R\&D. Bandung: Alfabeta. 